\title{
First country-wide survey of the Endangered Asian elephant: towards better conservation and management in Sri Lanka
}

\author{
Prithiviraj Fernando, M.K. Channa R. De Silva, L.K.A. Jayasinghe \\ H.K. JANAKA and JENNIFER PASTORINI
}

\begin{abstract}
The Endangered Asian elephant Elephas maximus comes into widespread conflict with agrarian communities, necessitating active management. The species' distribution is of primary importance for management planning. However, data-based countrywide distribution maps have not been available for any of the 13 Asian elephant range states. We conducted a $5 \times 5 \mathrm{~km}$ grid-based questionnaire survey in Sri Lanka to produce an island-wide elephant distribution map. Elephants occur over $59.9 \%$ of Sri Lanka and people are resident in $69.4 \%$ of elephant range, indicating the challenge of separating people and elephants at a landscape scale. Elephants in Sri Lanka have lost $16.1 \%$ of their range since 1960 but their current distribution remains largely contiguous. We found the range of adult males was $15.1 \%$ greater, and less seasonal, than that of herds, possibly because males have a higher tolerance for conflict with people. The distribution of conflict coincided with the co-occurrence of humans and elephants. We conclude that a human-elephant coexistence model is the only viable option for effectively mitigating human-elephant conflict and conserving elephants in Sri Lanka. The findings are currently being used to effect a paradigm change in elephant conservation and management in the country.
\end{abstract}

Keywords Asian elephant, conservation, distribution, Elephas maximus, human-wildlife conflict, Sri Lanka, survey

\section{Introduction}

The extent of a species' range is directly related to its
population size, and species distribution data are of primary importance for conservation and management (Mace, 1994; IUCN, 2001). Comprehensive survey data can indicate the best approach to species management, facilitate assessment of management efficacy at regional and country scales and inform appropriate interventions

Prithiviraj Fernando, M.K. (D http://orcid.org/0000-0001-6968-4189) Channa R. De Silva, L.K.A. Jayasinghe, H.K. Janaka and Jennifer Pastorini ${ }^{*}$ (Corresponding author, (D) http://orcid.org/0000-0001-5883-0208) Centre for Conservation and Research, 26/7 C2 Road, Kodigahawewa, Julpallama, Tissamaharama, Sri Lanka

${ }^{\star}$ Also at: Anthropologisches Institut, Universität Zürich, Zürich, Switzerland

Received 20 March 2018. Revision requested 22 May 2018.

Accepted 11 September 2018. First published online 6 February 2019. at local scales. Conservation planning, i.e. identifying and prioritizing conservation areas, is often based on predicted species distributions because survey data are incomplete or not available (Wilson et al., 2005). The uncertainty inherent in predicted data makes such an approach less than ideal for species-specific management, especially when intervention is required, as in human-wildlife conflict mitigation.

The Asian elephant Elephas maximus is categorized as Endangered on the IUCN Red List (Choudhury et al., 2008) and is currently limited to 13 South and South-east Asian range states (Fernando \& Pastorini, 2011). Asian elephants have a sexually dimorphic social structure, with adult females and young forming closely bonded groups, and dispersal of pubertal males (Fernando \& Lande, 2000). Adult males are mostly solitary and are more likely to use crops, adopting a high risk-high gain strategy (Sukumar \& Gadgil, 1988). Most incidents of human-elephant conflict involve adult males (Fernando, 2011).

The Asian elephant is unique as an Endangered species in coming into widespread and intense conflict with people, requiring active management for its conservation and for conflict mitigation. In Sri Lanka alone c. 70 people and 250 elephants lose their lives annually as a result of human-elephant conflict (Fernando et al., 2011). Most elephant management activities are directed towards conflict mitigation, often at the cost of elephant conservation (Fowler \& Mikota, 2008; Fernando \& Pastorini, 2011). Across Asian elephant range, elephant management has been based on confining elephants to protected areas (Fernando \& Pastorini, 2011). Human-elephant conflict occurs entirely outside protected areas and has continued to escalate over the past few decades, necessitating a rethink of management approaches (Fernando et al., 2006; Fernando \& Pastorini, 2011).

Asian elephants are forest animals, which makes their detection challenging. In Sri Lanka they mostly occupy lowvisibility habitat such as scrub and secondary forest during the day, venturing into the open only at night. Most Asian elephants come into conflict with people, and therefore they actively avoid people and/or respond aggressively to close approach (Fernando et al., 2008). Asian elephant densities vary from $<0.1$ elephants $/ \mathrm{km}^{2}$ in rain forests to c. 4 elephants $/ \mathrm{km}^{2}$ in grassland-savannah habitats (Sukumar, 1989), thus the Asian elephant is essentially a low-density species. Elephants also have home ranges of hundreds of 
$\mathrm{km}^{2}$ and can travel long distances, sometimes seasonally (Baskaran \& Desai, 1996; Fernando et al., 2008; Alfred et al., 2012), adding further complexity to detection. Although methods based on direct sighting of elephants and elephant signs such as droppings, footprints and evidence of feeding can be used to establish elephant presence (Hedges, 2012), their implementation at countrywide scales is difficult (but see Jathanna et al., 2015).

Rural communities in Asia are largely dependent on agriculture. Where elephants are present in agricultural neighbourhoods they almost invariably use crops, provoking strong negative emotions among residents. Although elephants generate universal interest, most South Asian populaces have close cultural and religious ties to elephants and identify closely with them (Sukumar, 2011; Gogoi, 2018). This counterbalances negative attitudes towards elephant conservation (Bandara \& Tisdell, 2004) and makes elephants and their whereabouts a matter of keen interest to local communities. Thus, communities tend to be aware of the presence or absence of elephants in their neighbourhood. Questionnaire surveys have been used to ascertain the distribution of a wide variety of species, including mountain lions Puma concolor (Berg et al., 1983), chimpanzees Pan troglodytes (Sugiyama \& Soumah, 1988), Sika deer Cervus nippon (Kaji et al., 2000), adders Vipera berus (Reading et al., 1996), squirrels Sciurus spp. (Teangana et al., 2000) and polecats Mustela putorius (Baghli \& Verhagen, 2003). Because of the way Asian elephants behave and interact with communities, a questionnaire-based approach should be suitable to determine their current distribution and how this has changed over time.

A number of studies have surveyed Asian elephant distribution in particular areas. Hedges et al. (2005) conducted a survey of elephant presence in Lampung Province $\left(33,307 \mathrm{~km}^{2}\right)$, Sumatra, based on questionnaire surveys and recce transects in areas where elephants were reported to be present. They also assessed elephant density in Bukit Barisan Selatan and Way Kambas national parks based on $286 \mathrm{~km}$ of line transects in an area of $4,803 \mathrm{~km}^{2}$ (Hedges et al., 2005). Jathanna et al. (2015) studied elephant presence in the Western Ghats of Karnataka, India, over an area of $38,540 \mathrm{~km}^{2}$, based on trail surveys of elephant habitat in 205 grid cells. The survey effort was proportional to the extent of suitable elephant habitat in each $188 \mathrm{~km}^{2}$ cell, with up to $40 \mathrm{~km}$ for a cell with $100 \%$ elephant habitat (Jathanna et al., 2015). Madhusudan et al. (2015) assessed elephant distribution in Karnataka, India, based on data for a 16-year period from multiple sources: dung counts on line transects, records of human-elephant conflict, media reports, opportunistic sightings, and sign and interview surveys. They overlaid the information on maps of 2,855 forest beats (smallest Forest Department administrative unit) with a median area of $31.53 \mathrm{~km}^{2}$ (range $0.6-1,802 \mathrm{~km}^{2}$ ) to produce a distribution map (Madhusudan et al., 2015). Here we present the results of a grid-based questionnaire survey of Asian elephant distribution in Sri Lanka.

\section{Methods}

\section{Interview survey}

We overlaid a map of Sri Lanka with $5 \times 5 \mathrm{~km}$ raster, creating 2,742 grid cells. A cell size of $25 \mathrm{~km}^{2}$ was chosen in preference to the $4 \mathrm{~km}^{2}$ recommended by IUCN (2001), based on a minimum home range size of $41 \mathrm{~km}^{2}$ for Sri Lankan elephants (Fernando et al., 2008) and logistical considerations. We surveyed by administering a questionnaire to residents in each cell. Interview locations within a cell were selected such that they were not clustered together. Survey locations and routes were identified from 1:50,000 topography maps from the Sri Lanka Survey Department.

From a pilot survey of 478 grid cells, with three respondents per cell, we found complete congruence of within cell responses in areas within and outside elephant range, but found variance at the boundaries. We then administered 10 questionnaires per cell in a sample survey of 25 cells with variable responses and scrutinized habitat and land use in presence/absence locations within a cell. We found that intra-cell variance was attributable to actual intra-cell spatial variation in elephant presence, and not type I or type II errors.

For the island-wide survey, based on logistical considerations, we chose to administer the questionnaire to three residents within each grid cell. In selecting respondents we visited each cell and chose individuals who had been resident for $>5$ years in that location, excluding those visiting or newly settled. Before administering the questionnaire we engaged the respondents in discussion and made a subjective assessment of their knowledge of the surroundings, and whether they were truthful. If in doubt, the questionnaire was not administered and another respondent was selected. In areas where there were no elephants we interviewed older people ( $\geq 60$ years) who had been resident in the cell their entire lives. A subjective assessment of each respondent was made in relation to reliability and knowledge of past events in the area, prior to recording the data. Interviews were conducted by MKCRDS and LKAJ during 2011-2015. The questionnaire was administered verbally and responses recorded on a standard data sheet. The geographical coordinates of each interview location were recorded using a global positioning system (GPS).

As interview surveys require detection, recall and reporting, it is possible that errors may occur, despite the safeguards taken. We therefore conducted an a posteriori test, using known-truth data (Chambert et al., 2015) from GPS 
tracking of 54 elephants during 2004-2018, to estimate false negatives in our questionnaire survey. We overlaid a total of 164,568 GPS locations from 28,469 tracking days on the survey results, and identified grid cells where elephant presence was not recorded in the survey but was indicated by the tracking data.

\section{Data analyses}

The data were analysed in Excel (Microsoft, Redmond, USA), and the maps were produced in QGIS (QGIS Development Team, 2016). We defined elephant presence as the year-round or seasonal presence of resident or non-resident adult males or herds within a grid cell. Cells in which elephants were reported to occur irregularly (once every few years) were considered not to have elephants present. A cell with 1-3 positive answers for elephant presence was categorized as 'elephants present', assuming that heterogeneity of responses reflected spatial heterogeneity within our mapping unit of $25 \mathrm{~km}^{2}$. Similarly, we used a hierarchy of elephant occupation states: herds $>$ males, resident $>$ passing through, and present all year $>$ present seasonally (dry or wet season only). From the three responses for each query within a cell we selected the higher state observed to represent the cell. For example, if one person stated that males passed through in the dry season, another stated that herds were resident in the dry season, and another that herds were resident all year, we categorized the cell as 'herds resident all year'. For cells without current elephant presence we took the most recent year stated for past presence to represent that cell. To assess the pattern of range loss, we grouped responses into 5-year categories for 2000-2015 and 10-year categories for 1960-2000.

A cell without people resident was assigned a state based on the four cells sharing a common boundary with it (firstorder neighbourhood), following the same hierarchy of states as before. Cells assigned a state in this manner were subsequently considered to be the same as cells categorized based on survey data.

To summarize human-elephant conflict for each grid cell we assigned the following values to the responses to the question 'How much of a problem are elephants?': none $=0$, $\operatorname{minor}=1$, moderate $=2$, major $=3$. We then calculated the mean value for each cell.

\section{Results}

Grid cells surveyed Interviews were conducted in 2,214 grid cells, covering $80.7 \%\left(55,350 \mathrm{~km}^{2}\right)$ of Sri Lanka. In nine cells ( $0.4 \%$ of total surveyed) only a single resident was interviewed, and in 34 cells (1.5\%) only two were interviewed. In 2,171 cells $(98.1 \%)$ we interviewed three residents. Five hundred cells $\left(18.2 \%\right.$ of Sri Lanka; $12,500 \mathrm{~km}^{2}$ ) had no residents and consisted mostly of protected areas. No data were obtained from 28 cells (1.0\% of Sri Lanka) because of logistics (promontories, water bodies) or error.

Elephant presence Of the 2,214 grid cells surveyed, 1,128 (50.9\%) had elephants (Fig. 1a). Of the 500 cells without residents, 497 were deemed to have elephants, based on first-order neighbourhood assignment. Thus, elephants were present in a total of 1,625 cells, of which 1,379 had both herds and males, and 245 had only males (Table 1 ; in one cell, herd presence was not specified). The herd range was $17.8 \%$ smaller than the male range. Cells with elephants present were contiguous, with the exception of two cell clusters in the south-west and a single cell in the south of the country, all of which indicated the presence of males only. Both south-western clusters included cells without people, corresponding to Forest Reserves.

A posteriori test for false negatives The 164,568 GPS locations covered a total of 264 grid cells, of which 257 (97.3\%) were identified as 'elephants present' in the survey (Fig. 1b). Elephant presence and elephant habitat occurred in only a fragment of each of the seven cells for which telemetry data indicated elephant presence but the interview survey did not.

Spatio-temporal patterns All grid cells with herds resident year-round also had resident males throughout the year. Males and herds were resident year-round in 88.6 and $60.9 \%$, respectively, of elephant range. In 8.7 and $20.3 \%$ of elephant range, males and herds, respectively, were resident only seasonally. Dry-season range was larger than wetseason range, with $69.7 \%$ of seasonal range of males and $66.1 \%$ of that of herds consisting of dry season only range. Males and herds passed through but were not resident in 2.6 and $3.7 \%$, respectively, of elephant range (Figs 1c, 2; Table 1).

Changes in elephant distribution In 1960 elephants were present in $71.3 \%$ of Sri Lanka (Fig. 3). Herd range in 1960 was $19.0 \%$ smaller than that of males. Males lost more of their range (16.1\%) than herds (12.1\%) during 1960-2015, with the majority of the decline occurring after 2005 (Fig. 4). In 41 grid cells (1.5\% of Sri Lanka) elephants were previously absent but are currently present.

Human-elephant conflict Of the 3,136 people with elephants in their neighbourhood, $55.7 \%$ said they had major problems with elephants. Another $23.1 \%$ said they had moderate problems and $14.2 \%$ had minor problems with elephants. A total of 219 people (7.0\%) said they had no problems with elephants. In 17 grid cells (1.5\%) with 

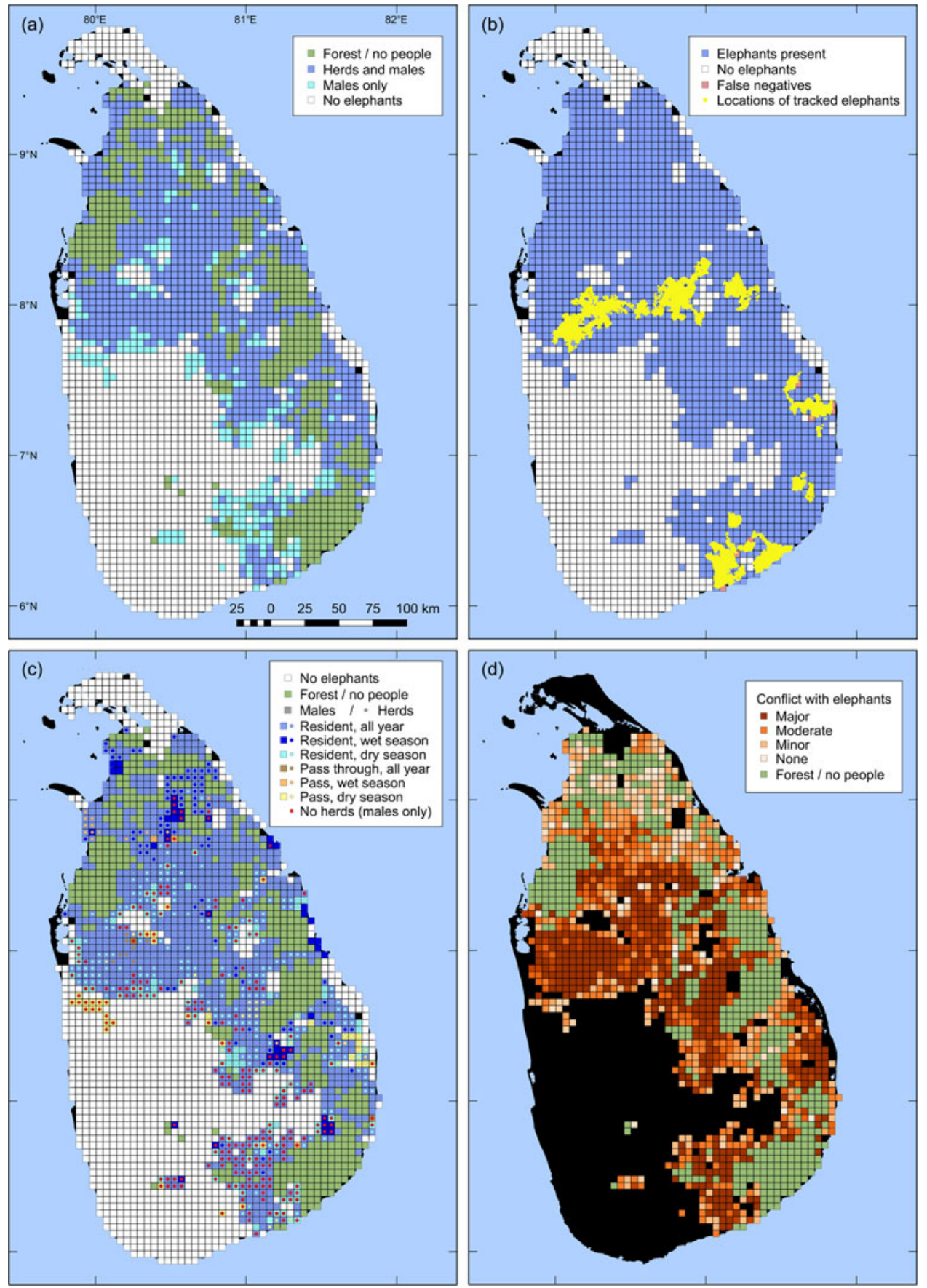

FIG. 1 Results of a countrywide survey of Asian elephant Elephas maximus distribution in Sri Lanka over 2,714 $5 \times 5 \mathrm{~km}$ grid cells. (a) Elephant presence, by herds and males; cells without resident people are coloured green.

(b) Elephant presence and absence overlaid with the GPS locations of 54 elephants tracked during 2004-2018.

(c) Spatio-temporal patterns of cell use by elephant herds and males (Fig. 2). (d) Severity of human-elephant conflict. both people and elephants present, all respondents said they had no problems with elephants. In all other cells there was some degree of conflict (Fig. 1d), with a mean score of $2.14 \pm$ SD $0.88(n=1,127)$.

\section{Discussion}

\section{Elephant distribution}

The countrywide distribution map of Asian elephants presented here is the first evidence-based map for a range state.
We found elephants had an area of occupancy (AOO) of $59.9 \%$ of Sri Lanka. Based on our a posteriori test for false negatives, the detection probability was $97.3 \%$. Thus we may have underestimated elephant distribution by $2.7 \%$, which amounts to $1.6 \%$ of the country. As grid cells with partial elephant presence were categorized as having elephants, our study could also have some bias towards overestimating elephant presence. However, such bias would only occur at the perimeter of elephant distribution, and given the relative scale of the survey and the grid size, we suggest that our estimate is robust and approximates the true distribution. 
TABLE 1 Details of the presence of male Asian elephants Elephas maximus and elephant herds in the 1,625 grid cells with elephants, from a countrywide survey of elephant distribution in Sri Lanka (2,742 grid cells).

\begin{tabular}{|c|c|c|c|c|}
\hline \multirow[b]{2}{*}{ Presence } & \multicolumn{2}{|l|}{ Males } & \multicolumn{2}{|l|}{ Herds } \\
\hline & No. of grid cells (\%) & Area $\left(\mathrm{km}^{2}\right)$ & No. of grid cells (\%) & Area $\left(\mathrm{km}^{2}\right)$ \\
\hline \multicolumn{5}{|l|}{ Resident } \\
\hline All year & $1,440(88.6)$ & 36,000 & $989(60.9)$ & 24,725 \\
\hline Wet season & $43(2.6)$ & 1,075 & $112(6.9)$ & 2,800 \\
\hline Dry season & $99(6.1)$ & 2,475 & $218(13.4)$ & 5,450 \\
\hline \multicolumn{5}{|l|}{ Pass through } \\
\hline All year & $2(0.1)$ & 50 & $9(0.6)$ & 225 \\
\hline Wet season & $3(0.2)$ & 75 & $15(0.9)$ & 375 \\
\hline Dry season & $38(2.3)$ & 950 & $36(2.2)$ & 900 \\
\hline Never present & $0(0)$ & 0 & $245(15.1)$ & 6,125 \\
\hline Unknown & $0(0)$ & 0 & $1(0.1)$ & 25 \\
\hline Total & $1,625(100)$ & 40,625 & $1,625(100)$ & 40,625 \\
\hline
\end{tabular}

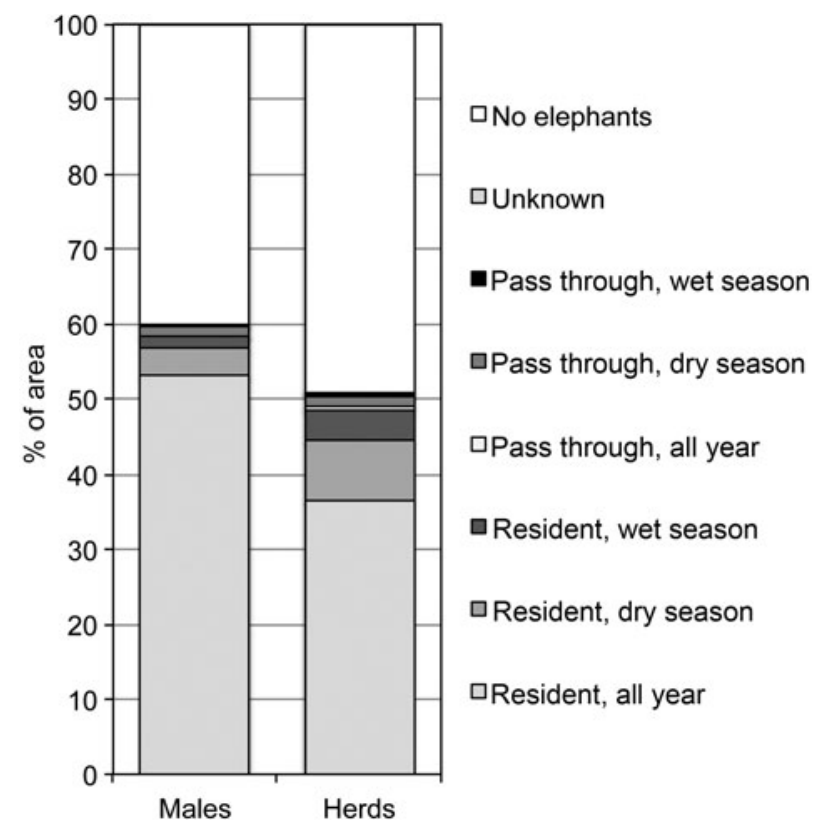

FIG. 2 Usage, as per cent of $2,7145 \times 5 \mathrm{~km}$ grid cells, by male elephants and elephant herds, from a countrywide survey of elephant distribution (Fig. 1c).

Previous estimates of elephant distribution in Sri Lanka based on expert opinion have suggested an AOO of c. 24.9\% (Olivier, 1978; percentage assessed by us from published map), c. 47.8\% (Hoffman, 1978; percentage assessed by us from published map), $>12 \%$ (Sukumar, 1989), 9.3\% (Santiapillai \& Jackson, 1990), 42.4\% (Leimgruber et al., 2003) and 36\% (de Silva \& de Silva, 2007). As none of these studies provided a definition of elephant presence, direct comparison may not be appropriate. However, compared to our findings, estimates of elephant distribution in Sri Lanka based on expert opinion have consistently been underestimates.

The ratio between the number of elephants and the area of Sri Lanka is thought to be almost 10 times that for any other range state (Fernando et al., 2011). This disparity may be partly explained by the lower mean AOO of elephants for the other Asian elephant range states (14.4 \pm SD 13\% of country area; Leimgruber et al., 2003). Compared to most range states, the greater extent of elephant range outside protected areas in Sri Lanka may be another contributory factor, as disturbed habitats support higher elephant densities (Fernando \& Leimgruber, 2011; Pastorini et al., 2013; Evans et al., 2018; Ranjeewa et al., 2018).

African forest elephants in Gabon were found to avoid anthropogenic habitats (Barnes et al., 1991). In contrast, we found people were resident in $69.4 \%$ of elephant range in Sri Lanka, and therefore the majority of elephants occupied landscapes that were largely human-dominated, disturbed and agricultural. Similarly, in Karnataka, India, $55 \%$ of Asian elephant habitat was outside designated protected areas (Madhusudan et al., 2015). Determining whether the observed patterns are species- or population-specific must await wider assessment of African and Asian elephant populations.

Habitats with an intermediate disturbance regime support higher densities of Asian elephants than undisturbed forests (Fernando \& Leimgruber, 2011; Pastorini et al., 2013; Ranjeewa et al., 2018; Evans et al., 2018). In an analysis of Borneo elephant Elephas maximus borneensis ranging and habitat use, degraded and secondary forests were found to be of higher suitability for elephants than primary forests, but their value for elephant conservation is largely unappreciated (Evans et al., 2018). The conditions assumed to be requisite for Asian elephant conservation, such as large, unfragmented, protected wildlands (Sukumar, 1989; Santiapillai \& Jackson, 1990; Leimgruber et al., 2003), are brought into question by these findings. Although undisturbed, unfragmented areas are important, degraded and human-dominated landscapes may be critical habitats for Asian elephants, and hence their incorporation in elephant conservation plans is of vital importance for the species' survival. 

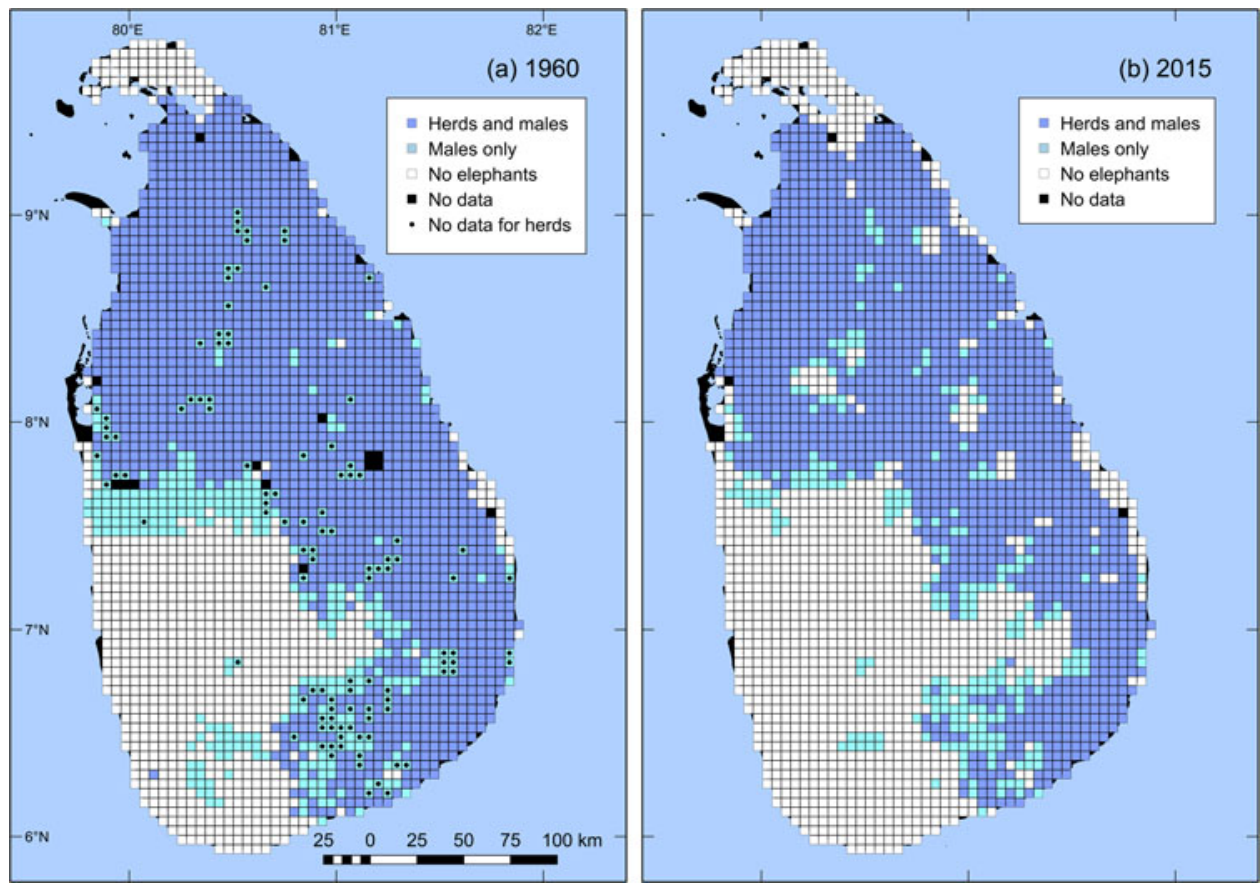

FIG. 3 Distribution of elephant herds and male elephants in Sri Lanka in (a) 1960 and (b) 2015 .

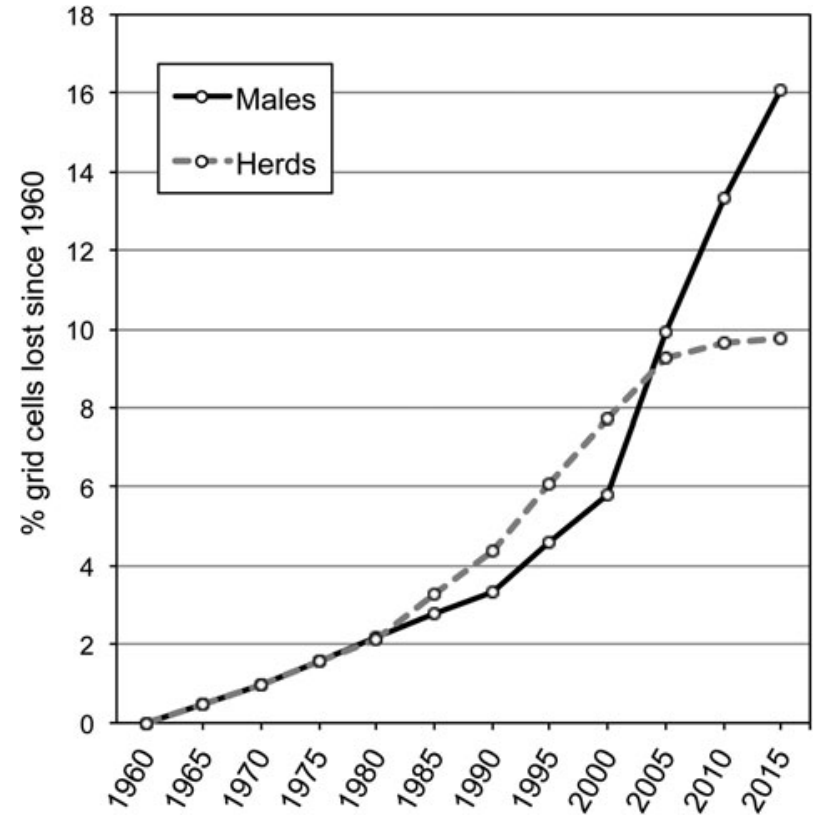

FIG. 4 Per cent of $2,7425 \times 5 \mathrm{~km}$ grid cells across Sri Lanka that lost male elephants and elephant herds between 1960 and 2015.

We found adult males were resident year-round over most of their range $(88.6 \%)$, whereas herds were resident year-round in only two thirds of their range (60.9\%). Herds were present seasonally and were non-resident in a greater portion of their range than were males. Higher tolerance of human disturbance and of conflict by males (Fernando, 2011) probably explains the sexual dimorphism in spatio-temporal patterns of occurrence.
We found elephant habitat without resident people covered $18.4 \%$ of Sri Lanka. The current extent of protected areas in Sri Lanka is $23.2 \%$ (IndexMundi, 2017). Almost all grid cells without people and located within elephant range had elephants (based on first-order neighbourhood assignment), indicating elephant presence in all protected areas. The inconsistency between elephant habitat without people and protected area extent is largely because some protected area categories (e.g. sanctuaries and proposed reserves) permit human habitation. Additionally, some $25 \mathrm{~km}^{2}$ cells partially consisted of protected areas without people, but had people resident in the remainder, and hence interviews were conducted and the cells categorized as having human presence.

\section{Population subdivision}

Our survey indicated that areas of elephant habitat in Sri Lanka are almost entirely contiguous, and therefore Sri Lankan elephants are not geographically subdivided but a single population. Of the isolated clusters identified, the two in the south-west correspond to the Peak Wilderness and Sinharaja forest reserves, which are the only wet zone habitats still occupied by elephants (Fernando et al., 2011). Peak Wilderness currently harbours c. 15 elephants, and Sinharaja 2-3 adult males (Fernando et al., 2011). Although there are no electric fences or other barriers preventing elephant movement out of the two areas, these elephants are thought to be isolated from other elephant range by densely populated and developed areas. Our results suggest that the Sinharaja population 
was contiguous with the dry zone populations to the east c. 50 years ago, but we found no evidence of current connectivity. Conclusive evidence of current isolation or connectivity can be obtained only through radio-tracking.

The notion that elephant groups become isolated and non-viable as a result of development has given rise to the idea of so-called pocketed elephants in the dry zone of Sri Lanka, and their removal by translocation or capture has been suggested (Somasuntharam et al., 1959; Olivier, 1978; Seidensticker, 1984; Santiapillai \& Jackson, 1990; Jayewardene, 1994; Lair, 1997). Our survey results indicate that dry zone elephant range is continuous, and that such management may be inappropriate. Removing pocketed elephants has also been discussed elsewhere, including in India (Gubbi et al., 2014) and Sumatra (Fowler \& Mikota, 2008). Based on our findings in Sri Lanka we advocate assessing the population viability of alleged pocketed elephants based on data on elephant distribution, ranging patterns, demography and health status, prior to any intervention.

\section{Sexual segregation}

We found some areas harboured only males, and therefore herd range was less than that of adult males. Spatial segregation of the sexes has been observed in African elephants and has been attributed to closer association of herds with water sources and displacement of non-musth males by musth males (Stokke \& Du Toit, 2002), differential forage selection between males and herds (Shannon et al., 2006), and either exploitation of resources inaccessible to female herds by males or competitive exclusion of males by female herds (Evans \& Harris, 2012). We found that all areas with female herds also had adult males, thus ruling out displacement or competitive exclusion of males as possible explanations.

Male-only areas in our study occurred mostly at the perimeter of elephant distribution. The exclusively male areas were zones where highly developed and densely populated areas graded into agricultural, less heavily populated areas, characteristic of elephant range. A probable explanation of the observed pattern is that adult males tolerate higher human densities and development, and hence more conflict, than herds. Thus in a sense the sexual segregation observed could be considered differential forage selection and male exploitation of resources inaccessible to female herds. However, the driver of sexual segregation in Sri Lanka is anthropogenic rather than natural.

\section{Seasonality of ranges}

Circa one eighth of the range of males and one fourth of herd range was seasonal, with approximately two thirds of the seasonal range for both males and females consisting of dry season only range. Seasonal ranges of elephants in Africa have been associated with periodicity of primary productivity and availability of surface water (Young et al., 2009). However, Sri Lankan elephants do not have spatially segregated seasonal ranges and do not migrate (Fernando et al., 2008). Seasonal agriculture facilitates temporal resource partitioning between people and elephants, with shifting cultivation being particularly beneficial to elephants (Pastorini et al., 2013). Therefore, seasonally used areas observed in our survey may be seasonal agriculture areas within the home ranges of elephants.

\section{Changes in elephant distribution}

We found elephants extirpated from c. one sixth of the range they occupied c. 50 years ago. Although recall over time scales of decades may be subject to lack of constancy and precision, the trend indicated (Fig. 4) is plausible. Elephants occurred over almost the entire island during the 17th century, with reported presence in current urban locales, including Colombo, Ratnapura and Kandy, during or after the 1600 s (McKay, 1973). Therefore Sri Lankan elephants lost c. $30 \%$ of their range during the 350 -year period prior to 1960 , and another $15.2 \%$ since then, indicating an acceleration of range loss. Although not comparable to the substantial losses in regions such as Sumatra, where elephants have lost $69 \%$ of their range since the early 1990 os (Gopala et al., 2011), the range decline in Sri Lanka has been persistent and is likely to continue.

Although elephant range expansion has been reported previously in Sri Lanka (Fernando et al., 2011), we found it to be negligible at a countrywide scale, accounting for only $2.5 \%$ of the current range. However, such changes may have a disproportionate impact on human-elephant conflict, bringing elephants into contact with communities unaccustomed to their presence.

There is a direct correlation between spatial distribution and abundance (Brown, 1984; Mace, 1994; Venier \& Fahrig, 1996), especially in populations at carrying capacity. In the absence of a recent significant reduction of elephant numbers independent of habitat loss, we should assume the Sri Lankan population to be at carrying capacity. Therefore, the pattern of range loss observed indicates a long-standing and increasing rate of elephant population decline. There is a popular belief in Sri Lanka that the elephant population has increased since the 1950s (Hoffmann, 1978; Santiapillai et al., 2010; Department of Wildlife Conservation, 2013; Santiapillai, 2013), based on various guesstimates of elephant numbers over time, and surveys using inappropriate methodology (Fernando, 2008; Jathanna et al., 2015). Such a scenario implies that increasing elephant numbers are the cause of an escalation in human-elephant conflict, and has been used to advocate for relaxation of conservation efforts 
and/or control of the elephant population to mitigate conflict (Santiapillai et al., 2010). Our survey results show the fallacy of this argument and underscore the danger of basing management decisions on assumptions.

The loss of elephant range was greater in areas occupied only by adult males compared to areas occupied by herds and males. Loss of male-only range represents local extinction, whereas loss of herd range may represent elimination of elephants or conversion to male-only range. We did not observe any direct conversion of herd range to non-elephant areas. Therefore, the progression of local extinction appears to be via conversion of herd range to male-only range. In Sri Lanka the cause of elephant range loss is development, in particular conversion of natural habitat to irrigated agriculture. As adult males tend to tolerate higher levels of conflict than herds (Fernando, 2011), they probably persist during the early phases of development but are eliminated as development continues.

Range loss appears to have been steady until c. 2005, when the decrease in herd range appears to have plateaued and that of male-only range to have increased. New irrigation development in Sri Lanka peaked in the mid 1980s and has continued since then, with greater outlay on rehabilitation and private investment (Kikuchi et al., 2002; Abayawardana et al., 2006). Local extinction may follow a lag period of a couple of decades after infrastructure development, related to settling and farming of developed land. The difference in trajectories of range loss between herds and males may reflect sexually dimorphic responses to changes in the pace and type of development and ensuing human-elephant conflict.

\section{Human-elephant conflict}

We found people were resident in almost $70 \%$ of elephant range, and there was conflict between elephants and people wherever they co-occurred. Consequently the map of human-elephant conflict approximately coincides with that of elephant presence outside protected areas (Figs 1a,d). Over much of the elephant's range a high level of human-elephant conflict was observed. There were some grid cells with lower levels of conflict in the northern areas (Fig. 1d), probably related to the lower human densities and the influence of 26 years of armed conflict, which ended in 2009. Current information from the north and east indicates escalation of human-elephant conflict to high levels since our survey.

\section{Importance as a survey method}

Conflict with people is the biggest threat to Asian elephants (Fernando \& Pastorini, 2011). Questionnaire surveys provide information on elephants that share space with people, and hence the most threatened populations. Such surveys sample a temporal and spatial scale commensurate with respondents' experiences. Compared to methods requiring elephant or sign detection, questionnaire surveys sample a greater temporal and spatial scale and are less labour intensive, logistically simpler and applicable to large landscapes.

False positives are unlikely in detection surveys but are possible with questionnaire surveys if the respondent is untruthful or is unable to relate accurately to the area in question. Therefore it is important to make a subjective assessment of the respondent in administering questionnaires. We expect limiting queries to the immediate neighbourhood of residents, as we did, would prevent confusion about the area.

Although false negatives are a problem with detection surveys, they are less likely in questionnaire surveys, given the spatial and temporal scales sampled, as indicated by the test for false negatives in our survey. As conflict between people and elephants mostly involves adult male elephants, the observed coincidence of human-elephant co-occurrence and human-elephant conflict suggests a high detection probability of males via questionnaire surveys. Where elephants are limited to areas without resident people, questionnaire surveys may fail to detect elephant presence. Such an instance occurred in our survey, where the presence of herds in the Peak Wilderness area was not detected and neighbourhood assignment categorized it as a male-only area. This was not a problem for the current survey as it accounted for only $0.1 \%$ of the survey area. However, it may be of concern in large landscapes with low human densities, necessitating fewer interviews and/or larger minimum mapping units. Ideally questionnaire surveys should be combined with ground surveys for elephants and elephant signs, particularly in areas without resident people.

We were able to survey the entire land area of Sri Lanka, but countrywide surveys may be logistically challenging in larger countries. Sri Lanka is an exception among range countries in having a high Asian elephant AOO, and therefore covering the entire country was deemed to be important in terms of both current and past elephant distribution. Although logistically challenging, it is not impossible to conduct countrywide surveys in larger countries where accessibility is high. However, surveys could also be limited to areas of known or possible elephant presence. Starting from an area of known elephant presence, surveys could be conducted until two grid cells without elephant presence are detected, so that a $10 \mathrm{~km}$ wide boundary without elephants is established around a landscape with elephants. In countries where knowledge of elephant presence is poor and human densities and accessibility may be low, a larger grid size, such as $10 \times 10 \mathrm{~km}$, could be used for an initial survey, followed by finer-grained surveys in areas with elephants.

\section{Management implications}

Elephants and people co-occurred in c. 70\% of current elephant range in Sri Lanka and human-elephant conflict 
occurred in almost all areas of overlap. Since the 1950 s the main approach to human-elephant conflict mitigation and elephant management in Sri Lanka has been the segregation of people and elephants at a landscape level, by confining elephants to protected areas (Somasuntharam et al., 1959; Fernando, 2015). Our survey results highlight the failure of this approach. Attempts to restrict elephants to protected areas, by elephant drives, leads to carrying capacity being exceeded, and decimation of elephant populations, and hence is detrimental to elephant conservation (Fernando, 2016). It also causes escalation of conflict in drive areas as a result of increased aggressiveness of elephants subject to drives but not removed (Fernando, 2015). Given that the majority of elephants in Sri Lanka share land with people, continued attempts to limit elephants to protected areas will lead to escalation of human-elephant conflict in the near term and, ultimately, loss of elephants. Therefore, the only option is to manage elephants in situ. We recommend a humanelephant coexistence model that promotes stakeholder awareness and mitigates conflict by protecting villages and cultivations with barriers such as electric fences. This approach has been incorporated into the National Policy for Elephant Conservation and Management in Sri Lanka but is yet to be fully implemented. The distribution map we have prepared serves as a template for identifying areas where conflict mitigation needs to be integrated into development plans, thus facilitating human-elephant co-existence and the prevention and reduction of humanelephant conflict. Under such management elephants will continue to range outside protected areas, ensuring their survival.

Acknowledgements We are grateful to Anoma Edirisooriya for data entry. The Abraham Foundation and Elephant Family provided financial support for this study.

Author contributions Data collection: HKJ, MKCRDS, LKAJ; data analysis: JP; writing: PF, JP.

\section{Conflicts of interest None.}

Ethical standards This research complied with the Oryx Code of Conduct.

\section{References}

Abayawardana, S., Marikar, F., Wijerathna, D. \& Gichuki, F. (2006) Development Strategy for the Irrigation Sector of Sri Lanka 2006-2016. International Water Management Institute, Colombo, Sri Lanka. Http://publications.iwmi.org/pdf/Ho40801.pdf [accessed 20 September 2018].

Alfred, R., Ahmad, A.H., Payne, J., Williams, C., Ambu, L.N., How, P.M. \& Goossens, B. (2012) Home range and ranging behaviour of Bornean elephant (Elephas maximus borneensis) females. PLOS ONE, 7, e3140o.
Baghli, A. \& Verhagen, R. (2003) The distribution and status of the polecat Mustela putorius in Luxembourg. Mammal Review, 33, 57-68.

BANDARA, R. \& Tisdell, C. (2004) The net benefit of saving the Asian elephant: a policy and contingent valuation study. Ecological Economics, 48, 93-107.

Barnes, R.F.W., Barnes, K.L., Alers, M.P.T. \& Blom, A. (1991) Man determines the distribution of elephants in the rain forests of northeastern Gabon. African Journal of Ecology, 29, 54-63.

Baskaran, N. \& Desai, A.A. (1996) Ranging behaviour of the Asian elephant (Elephas maximus) in the Nilgiri Biosphere Reserve, South India. Gajah, 15, 41-57.

Berg, R.L., McDonald, L.L. \& Strickland, M.D. (1983) Distribution of mountain lions in Wyoming as determined by mail questionnaire. Wildlife Society Bulletin, 11, 265-268.

Brown, J.H. (1984) On the relationship between abundance and distribution of species. The American Naturalist, 124, 255-279.

Chambert, T., Miller, D.A.W. \& Nichols, J.D. (2015) Modeling false positive detections in species occurrence data under different study designs. Ecology, 96, 332-339.

Choudhury, A., Lahiri Choudhury, D.K., Desai, A., Duckworth, J.W., Easa, P.S., Johnsingh, A.J.T. et al. (2008) Elephas maximus. In The IUCN Red List of Threatened Species 2008: e.T7140A12828813. Http://dx.doi.org/10.2305/IUCN.UK. 2008.RLTS.T7140A12828813.en [accessed 21 September 2018]

Department of Wildlife Conservation (2013) The First Island-wide National Survey of Elephants in Sri Lanka 2011. Department of Wildlife Conservation, Colombo, Sri Lanka.

De Silva, M. \& de Silva, P.K. (2007) The Sri Lankan Elephant: Its Ecology, Evolution and Conservation. WHT Publications (Pvt.) Ltd., Colombo, Sri Lanka.

Evans, K. \& Harris, S. (2012) Sex differences in habitat use by African elephants (Loxodonta africana) in the Okovango Delta, Botswana: is size really the deciding factor? African Journal of Ecology, 50, 277-284.

Evans, L.J., Asnera, G.P. \& Goossens, B. (2018) Protected area management priorities crucial for the future of Bornean elephants. Biological Conservation, 221, 365-373.

Fernando, P. (2008) Editorial. Gajah, 28, 1-2.

Fernando, P. (2011) Managing 'problem elephants'. Loris, 25, 32-36.

Fernando, P. (2015) Managing elephants in Sri Lanka: where we are and where we need to be. Ceylon Journal of Science (Biological Sciences), 44, 1-11.

Fernando, P. (2016) A calamity in Yala. Loris, 27, 39-40.

Fernando, P. \& Lande, R. (200o) Molecular genetic and behavioral analyses of social organization in the Asian elephant (Elephas maximus). Behavioral Ecology and Sociobiology, 48, 84-91.

Fernando, P. \& Leimgruber, P. (2011) Asian elephants and seasonally dry forests. In Ecology and Conservation of Seasonally Dry Forests in Asia (eds W.J. McShea, S.J. Davies \& N. Bhumpakphan), pp. 151-163. Smithsonian Institution Scholarly Press, Washington, DC, USA.

Fernando, P. \& Pastorini, J. (2011) Range-wide status of Asian elephants. Gajah, 35, 15-20.

Fernando, P., Wikramanayake, E.D., Weerakoon, D., Janaka, H.K., Gunawardena, M., Jayasinghe, L.K.A. et al. (2006) The future of Asian elephant conservation: setting sights beyond protected area boundaries. In Conservation Biology in Asia (eds J.A. McNeely, T.M. McCarthy, A. Smith, L. Olsvig-Whittaker \& E.D. Wikramanayake), pp. 252-26o. Society for Conservation Biology-Asia Section, Kathmandu, Nepal.

Fernando, P., Wikramanayake, E.D., Janaka, H.K., Jayasinghe, L.K.A., Gunawardena, M., Kotagama, S.W. et al. (2008) 
Ranging behavior of the Asian elephant in Sri Lanka. Mammalian Biology, 73, 2-13.

Fernando, P., Jayewardene, J., Prasad, T., Hendavitharana, W. \& Pastorini, J. (2011) Current status of Asian elephants in Sri Lanka. Gajah, 35, 93-103.

Fowler, M. \& Mikota, S.K. (eds) (2008) Biology, Medicine, and Surgery of Elephants. Blackwell Publishing, Oxford, UK.

Gogor, M. (2018) Emotional coping among communities affected by wildlife-caused damage in north-east India: opportunities for building tolerance and improving conservation outcomes. Oryx, 52, 214-219.

Gopala, A., Hadian, O., Sunarto, Sitompul, A., Williams, A., Leimgruber, P. et al. (2011) Elephas maximus ssp. sumatranus. In The IUCN Red List of Threatened Species 2011: e.T199856A9129626. Http://dx.doi.org/10.2305/IUCN.UK.2011-2.RLTS.

T199856A9129626.en [accessed 13 November 2017].

Gubbi, S., Swaminath, M.H., Poornesha, H.C., Bhat, R. \& Raghunath, R. (2014) An elephantine challenge: human-elephant conflict distribution in the largest Asian elephant population, southern India. Biodiversity and Conservation, 23, 633-647.

Hedges, S. (ed.) (2012) Monitoring Elephant Populations and Assessing Threats. Universities Press (India) Pvt. Ltd., Hyderabad, India.

Hedges, S., Tyson, M.J., Sitompul, A.F., Kinnaird, M.F., Gunaryadi, D. \& Aslan (2005) Distribution, status, and conservation needs of Asian elephants (Elephas maximus) in Lampung Province, Sumatra, Indonesia. Biological Conservation, $124,35-48$.

Hoffmann, T.W. (1978) Distribution of elephants in Sri Lanka. Loris, $14,366-367$.

IndexMundi (2017) Sri Lanka-Terrestrial Protected Areas. Http:// www.indexmundi.com/facts/sri-lanka/indicator/ER.LND.PTLD.ZS [accessed 18 September 2017].

IUCN (2001) IUCN Red List Categories and Criteria. Version 3.1. IUCN, Gland, Switzerland.

Jathanna, D., Karanth, K.U., Kumar, N.S., Karanth, K.K. \& Goswami, V.R. (2015) Patterns and determinants of habitat occupancy by the Asian elephant in the Western Ghats of Karnataka, India. PLOS ONE, 10, e0133233.

Jayewardene, J. (1994) Elephant drives in Sri Lanka. Gajah, 13, 30-39.

Kaji, K., Miyaki, M., Saitoh, T., Ono, S. \& Kaneko, M. (2000) Spatial distribution of an expanding Sika deer population on Hokkaido Island, Japan. Wildlife Society Bulletin, 28, 699-707.

Kikuchi, M., Barker, R., Weligamage, P. \& Samad, M. (2002) Irrigation Sector in Sri Lanka: Recent Investment Trends and the Development Path Ahead. IWMI Research Report 62. International Water Management Institute, Colombo, Sri Lanka.

LAIR, R. (1997) Gone Astray. The Care and Management of the Asian Elephant in Domesticity. FAO Regional Office for Asia and the Pacific, Bangkok, Thailand.

Leimgruber, P., Gagnon, J.B., Wemmer, C., Kelly, D.S., Songer, M.A. \& SELIG, E.R. (2003) Fragmentation of Asia's remaining wildlands: implications for Asian elephant conservation. Animal Conservation, 6, 347-359.

MACE, G.M. (1994) An investigation into methods for categorizing the conservation status of species. In Large Scale Ecology and Conservation Biology (eds P.J. Edwards, R.M. May \& N.R. Webb), pp. 293-312. Blackwell Scientific, Oxford, UK.

Madhusudan, M.D., Sharma, N., Raghunath, R., Baskaran, N., Bipin, C.M., Gubbi, S. et al. (2015) Distribution, relative abundance, and conservation status of Asian elephants in Karnataka, southern India. Biological Conservation, 187, 34-40.

McKay, G.M. (1973) Behavior and Ecology of the Asiatic Elephant in Southeastern Ceylon. Smithsonian Contributions to Zoology No. 125. Smithsonian Institution Scholarly Press, Washington, DC, USA.
Olivier, R. (1978) Distribution and status of the Asian elephant. Oryx, $14,379-424$.

Pastorini, J., Janaka, H.K., Nishantha, H.G., Prasad, T., Leimgruber, P. \& Fernando, P. (2013) A preliminary study on the impact of changing shifting cultivation practices on dry season forage for Asian elephants in Sri Lanka. Tropical Conservation Science, 6, 770-780.

QGIS Development Team (2016) QGIS Geographic Information System. Open Source Geospatial Foundation Project. https://www. qgis.org/en/site/ [accessed 14 November 2018].

Ranjeewa, A.D.G., Pastorini, J., Isler, K., Weerakoon, D.K., Kottage, H.D. \& Fernando, P. (2018) Decreasing reservoir water levels improve habitat quality for Asian elephants. Mammalian Biology, 88, 130-137.

Reading, C.J., Buckland, S.T., McGowan, G.M., Jayasinghe, G., Gorzula, S. \& Balharry, D. (1996) The distribution and status of the adder (Vipera berus L) in Scotland determined from questionnaire surveys. Journal of Biogeography, 23, 657-667.

Santiapillai, C. (2013) The difficulty in estimating the total population size of wild elephants in Sri Lanka. Ceylon Journal of Science (Biological Sciences), 42, 101-103.

Santiapillai, C. \& Jackson, P. (1990) The Asian Elephant: An Action Plan for its Conservation. IUCN, Gland, Switzerland.

Santiapillai, C., Wijeyamohan, S., Bandara, G., Athurupana, R., Dissanayake, N. \& Read, B. (2010) An assessment of the human-elephant conflict in Sri Lanka. Ceylon Journal of Science (Biological Sciences), 39, 21-33.

Seidensticker, J. (1984) Managing Elephant Depredation in Agricultural and Forestry Projects. Technical paper, The World Bank, Washington, DC, USA.

Shannon, G., Page, B.R., Duffy, K.J. \& Slotow, R. (2006) The role of foraging behaviour in the sexual segregation of the African elephant. Oecologia, 150, 344-354.

Somasuntharam, K., Spittel, R.L., Jayawardena, C.P., Somanader, S.V.O., Coombe, G., Norris, C.E. et al. (1959) Sessional Paper XIX. Report of the Committee on Preservation of Wild Life. Government Press, Colombo, Sri Lanka.

Stокке, S. \& Du Toit, J.T. (2002) Sexual segregation in habitat use by elephants in Chobe National Park, Botswana. African Journal of Ecology, 40, 360-371.

Sugiyama, Y. \& Soumah, A.G. (1988) Preliminary survey of the distribution and population of chimpanzees in the Republic of Guinea. Primates, 29, 569-574.

Sukumar, R. (1989) The Asian Elephant: Ecology and Management. Cambridge University Press, New York, USA.

Sukumar, R. (2011) The Story of Asia's Elephants. The Marg Foundation, Mumbai, India.

SukUMAR, R. \& GadgiL, M. (1988) Male-female differences in foraging on crops by Asian elephants. Animal Behaviour, 36, 1233-1235.

Teangana, D.O., Reilly, S., Montgomery, W.I. \& Rochford, J. (2000) Distribution and status of the red squirrel (Sciurus vulgaris) and grey squirrel (Sciurus carolinensis) in Ireland. Mammal Review, $30,45-56$.

Venier, L.A. \& Fahrig, L. (1996) Habitat availability causes the species abundance-distribution relationship. Oikos, 76, 564-570.

Wilson, K.A., Westphal, M.I., Possingham, H.P. \& Elith, J. (2005) Sensitivity of conservation planning to different approaches to using predicted species distribution data. Biological Conservation, 122, 99-112.

Young, K.D., Ferreira, S.M. \& Van Aarde, R.J. (2009) Elephant spatial use in wet and dry savannas of southern Africa. Journal of Zoology, 278, 189-205. 